\title{
Prevalence of human immunodeficiency virus, hepatitis B virus, hepatitis $C$ virus, and syphilis in blood donors in a tertiary health facility in south eastern Nigeria
}

\author{
Huldah ljeoma Nwokeukwu', Collins Ogbonna Nwabuko ${ }^{*}$, Abali Chuku², Eno Ajuogu and Okoh Adaunwa Dorathy \\ *Correspondence: ogbollins2002@yahoo.com

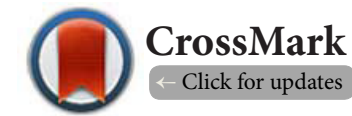 \\ 'Departments of community Medicine and Hematology, Federal Medical Centre, Umuahia, Abia State, Nigeria. \\ ${ }^{2}$ Department of Ophthalmology, Federal Medical Centre, Umuahia, Abia State, Nigeria. \\ ${ }^{3}$ Department of Pathology, Braithwaith Memorial Hospital, Port Harcourt, Rivers State, Nigeria.
}

\begin{abstract}
Background: Blood donation is a very important life saving intervention in health care services. It is also known that some diseases are transmitted from the seemly healthy blood donors like HIV, Hepatitis B, Hepatitis C and Syphilis and WHO has recommended that these diseases should be screened to get safe blood. Since screening of blood donors is done in this health facility, it is therefore necessary to know the prevalence of HIV, HBV, HCV and syphilis in these blood donors. This study aimed at determining the seroprevalence of HIV, HBV, HCV and Syphilis in prospective blood donors in our health institution.

Methodology: This was a retrospective study. The records of the blood donors were reviewed and Biodata and positivity of the diseases were collected. Data was analyzed with Excel and Epi-info.

Results: The total of 2626 blood donors were recruited in 2012 out of which 2292 (87.3\%) were males, 271 (10.3\%) females, [P value<0.0000000 CI 4.8089-15.7397] and 63, undocumented gender (2.4\%). Majority of the donors were within the age group $29-39(43.3 \%, \mathrm{~N}=1143)$. The seroprevalance of HIV, HBV, HCV and Syphilis were $0.3 \%(\mathrm{~N}=8), 0.3 \%(\mathrm{~N}=8), 0.2 \%(\mathrm{~N}=5), 0.1 \%(\mathrm{~N}=3)$ respectively. All the cases were males.

Conclusion: The study revealed a low prevalence of transfusion transmissible infectious agents among our prospective blood donors. It could be that people who know their status do not come for blood donation or as a result of other challenges confronting safe blood practices in sub-Saharan Africa.
\end{abstract}

Keywords: HIV, HBV, HCV, syphilis, blood transfusion

\section{Introduction}

Blood transfusion is a life saving intervention that is essential in the management and care of patients. In 2005, all member states of WHO signed a document that commits them to the provision of safe and adequate blood and blood products to patients [1]. In high-income countries, transfusion is most commonly used to support advanced medical treatment and complex surgeries like open-heart surgery and advance trauma care, whereas in sub-Saharan Africa, it is used mainly to correct anaemia from infections such as malaria and hookworm, malnutrition, surgical and obstetric emergencies apart from acute blood loss from road traffic accident [2].

The safety of blood is a major source of concern when blood transfusion is required for what ever reason especially in a developing country such as ours where national blood transfusion services and policies, appropriate infrastructure, trained personnel and financial resources are inadequate [3]. This concern stems from the fact that there is a wide spectrum of blood borne infections which can be transmitted through the blood of apparently healthy and asymptomatic blood donors. These transfusion transmissible infectious agents include hepatitis $B$ virus (HBV), hepatitis $C$ virus (HCV), human immunodeficiency viruses (HIV-1/2), human T-cell lymphotropic viruses (HTLV-I/II), Cytomegalovirus (CMV), Parvovirus B19, West Nile Virus (WNV), Dengue virus, trypanosomiasis, Syphilis and malaria [4]. This scenario is worsened by the method of replacement of blood either by family members or paid donors as against WHO recommended voluntary donors [1]. Regular, 
Nwokeukwu et al. Hematology and Leukemia 2014,

voluntary, unpaid blood donors are the safest group of donors as the prevalence of blood borne infections is lowest among these donors [1].

WHO recommends that universally, blood for transfusion be screened for HIV, HBV, HCV and Syphilis. In selected countries depending on epidemiological evidence, screening should be done for the following also; malaria, Chagas disease, Human T-cell lymphotropic viruses $1 \& 2$ and Human Cytomegalovirus [1]. In Nigeria, the national blood transfusion guideline stipulates that donor blood should be screened for specified Transfusion-Transmissible Infections including Human Immunodeficiency Virus (HIV), HBV, HCV and Syphilis [5]. In Federal Medical Centre, Umuahia, screening is carried out for HIV, HBV, HCV and syphilis.

Human immune deficiency virus, HBV and HCV are of particular concern because of their prolonged infectivity, carrier state and the fact that they also cause various debilitating disorders which may eventually be fatal [6]. Though these viruses can also be transmitted through other means, infectivity estimates for the transfusion of infected blood products are much higher (92\%) than for other modes of transmission owing to the much larger viral dose per exposure than for other routes [7].

Transfusion of infected blood is the cause of $5-10 \%$ of HIV infections in sub-Saharan Africa [8], and $12.5 \%$ of patients who receive blood transfusions are at risk of post-transfusion hepatitis [9].

It is also important to discourage and as much as possible eliminate commercial and replacement blood donation by relations of the person as such persons have been shown to be likely to test positive for blood transmitted infections [10].

Although blood transfusion contributes relatively little to the overall HIV and other pathogen transmission, prevention of infection through blood transfusion is a priority for ethical reasons. Apart from this, whatever quantity of the pathogen that is present in blood for transfusion is most likely to be transmitted to the recipient as the blood will act as a direct vehicle. The median overall risks of becoming infected with HIV $\mathrm{HBV}$, and HCV from a blood transfusion in sub-Saharan Africa were 1, 4.3, and 2.5 infections per 1000 units, respectively [11] while in the developed countries the estimate is $1 / 2600000$ for HIV, 1/6 500000 for HCV, 1/1 700000 for HBV [12]. Several studies have been carried out to assess the prevalence of HIV, $\mathrm{HBV}$, and HCV among blood donors in several countries. This became very crucial since the HIV epidemic appears to be worse in Sub -Saharan Africa [13].

There is therefore a need for continuous monitoring of the seroprevalence of HIV, HBV, HCV and Syphilis that cause life threatening morbidities among blood donors so as to estimate the risk of infection and put in place better blood donor recruitment policies that will make blood safer for the recipients especially in a tertiary health facility like Federal Medical Centre, Umuahia, Abia State, Nigeria. This study aimed to determine the seroprevalence of HIV, HBV, HCV and Syphilis in prospective blood donors who visit the blood bank of the above health institution.

\section{Methodology}

The retrospective study site was Federal Medical centre (Queeen Elizabeth Specialist Hospital, QESH). Federal Medical Centre is the only tertiary Federal health facility in Abia state. It is located in Umuahia, the capital of Abia State. Abia State is in the South Eastern Nigeria. Blood samples ( $3 \mathrm{mls}$ of venous blood in a syringe) from 2626 prospective donors (not less than 18 years) were tested for the presence of antibodies to HIV 1/2, HCV, Syphilis, HCV and HBs Ag using the National AIDS control Organisation ELISA rapid test kits. The categories of donors that were present in this study were mainly commercial/ replacement with very few voluntary donors. A voluntary donor is one who is not paid for the donated blood. A replacement donor is a donor who donates blood for a particular patient admitted in the hospital; he may or may not have been paid by the patient.

The records of the blood donors were reviewed from January to December 2012 and Bio-data and positivity of the diseases were collected. Ethical approval was gotten from the ethical committee of Federal Medical Centre, Umuahia.

Data was analyzed with Excel and Epi-info. The statistical test used is chi-square for comparison of variables and $95 \%$ confidence interval.

\section{Results}

The total number of blood donors in 2012 were 2626 out of which males represented the majority $(87.3 \%, \mathrm{~N}=2292)$, followed by females $(10.3 \%, \mathrm{~N}=271)$ and undocumented gender $(2.4 \%, \mathrm{~N}=63)$. The majority $(43.3 \%, \mathrm{~N}=1143)$ of the donors were within the age group 29-39 years. The seroprevalence of HIV, HBV, HCV and syphilis were $0.3 \%(\mathrm{~N}=8), 0.3 \%(\mathrm{~N}=8)$, $0.2 \%(\mathrm{~N}=5), 0.1 \%(\mathrm{~N}=3)$ respectively. All the infected donors were males (Figure 1). No infectious agent was isolated from the donors above 47 years old and female gender in the study (Figures 2 and 3 respectively). HIV and HBV $(0.3 \%$ each, $\mathrm{N}=8$ ) ranked highest followed by $\mathrm{HCV}(0.2 \%, \mathrm{~N}=5)$ and Syphilis $(0.1 \%, \mathrm{~N}=3)$ which had the least prevalence.

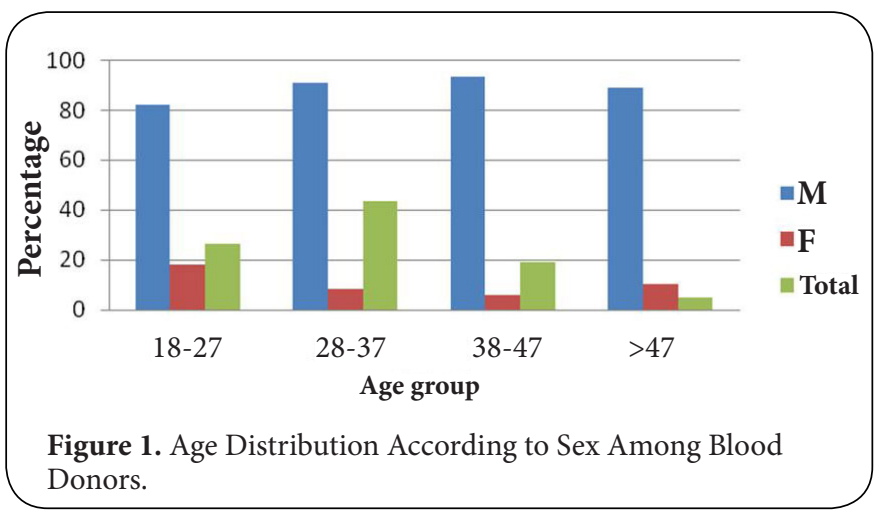




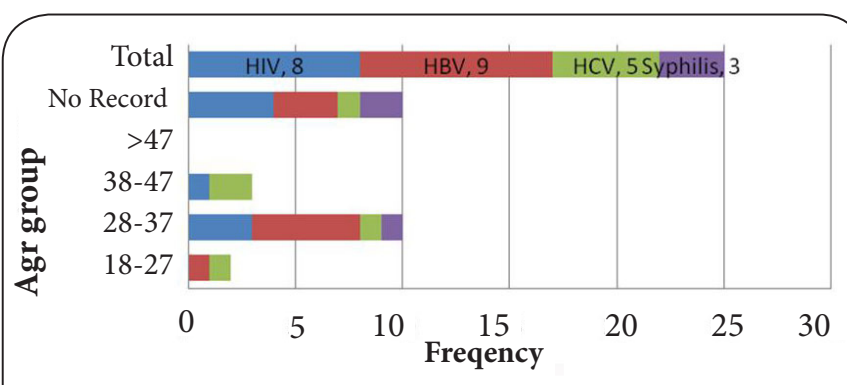

Figure 2. Age Distribution According to The Infectious Agent.

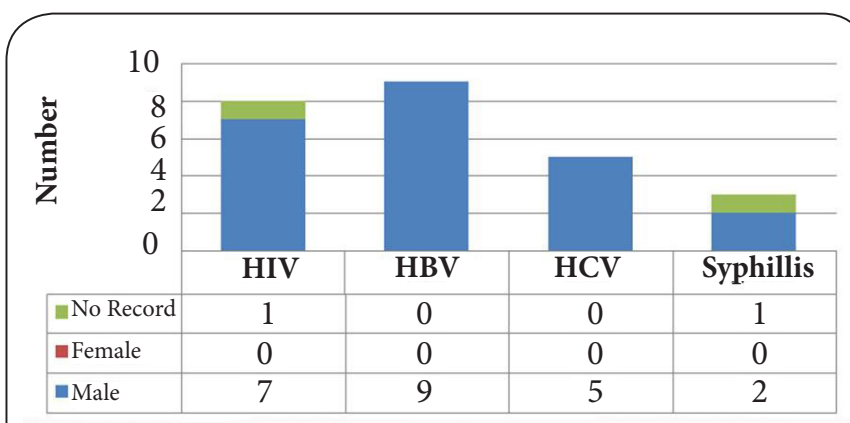

Figure 3. Sex Distribution According to Infectious Agent In Blood Donors.

\section{Discussion}

The data showed that the prevalence of HIV, HBV, HCV and Syphilis was low among prospective blood donors screened in our health facility. This is in contrast to some studies done in this country [14-19]. It is also in contrast with studies done in other parts of the world with higher prevalence for the infectious agents, in Burkina Faso [20], Cameroun [21], Mali [22], Mozambique [23], Democratic republic of Congo [24,25] and in Tanzania [26]. Although in Democratic Republic of Congo there was no case of HCV seen [23] which is lower than what was found in this study. In some studies done where it was differentiated between the commercial and replacement donors, the prevalence in replacement donors was similar to the result from this study $[\mathbf{1 7 , 1 8}]$. It may be due to the fact that most of the blood donors were mainly commercial/replacement donors. Although when replacement and voluntary donors were compared, the prevalence was lower in voluntary donors compared to commercial/family replacement counterparts. Another possible reason could be that most people who know their status (seropositive) may not present themselves for blood donation. Furthermore, the blood screening process could be another reason for the low data. In this region, we are still relying only on antibody-based mode of screening which lacks the capacity to detect antigen of infected blood at the window phase. The government and donor agencies owe it as a responsibility to address this mode of screening in our regional blood banks in sub-Saharan Africa.

This study also showed a statistically significant gender inequality among the blood donors with the males greater than females. The increase in the male:female ratio [(M:F 10:1; $p<0.05)$ ] shows that more males donate blood than females in our environment. Although this may be what is obtainable elsewhere in sub-Saharan Africa, however, this study has further shown that very few women in our environment donate blood compared to their male counterparts. This could be due to physiological changes such as monthly menstrual flow, pregnancy and lactation. It could also be due to lack of proper public health awareness (education) on the essence of blood donation in our regional blood banks.

However, among the female donors, there was no infectious agent seen in their blood. The entire infectious agents were seen among male donors. Several factors could be attributable to this: it could be as a result of small population size of women who participated in this study compared to their male counterparts or due to improper documentation of the gender results. There were about 3 donors who tested seropositive without gender documentation. In Figure 4, it was shown that most of the donors with infectious agents (about 10) did not have their records complete (either gender or age). Another major challenge in blood transfusion practice in sub-Saharan Africa is lack of proper documentation of biomedical datas of prospective blood donors. This has led to mismatch of blood, re-emergence of transfusion transmissible infections, adverse blood transfusion reaction and paucity of accurate data for research works in this region. This retrospective study is a typical scenerio of what happens in resource-limited settings of sub-Saharan Africa.

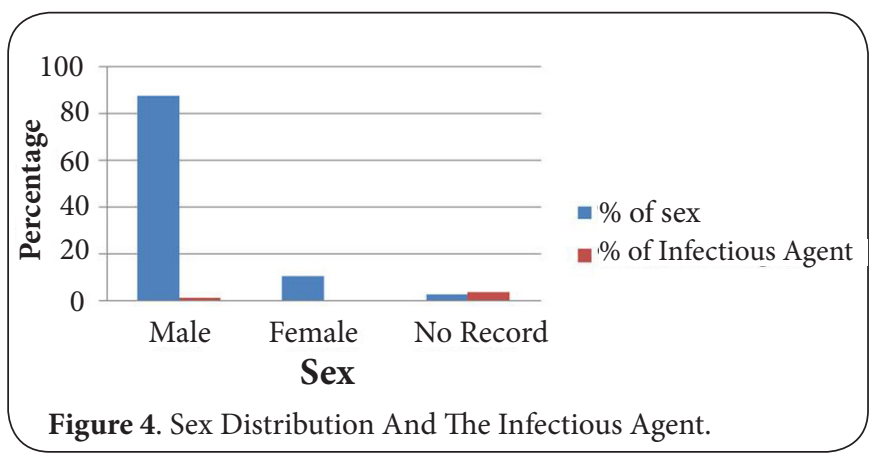

The age group 28-37 years had the highest prevalence of infectious agents while no infectious agent was detected in the ages above 47 years. This showed that the infectious agents are seen more in the younger age groups. Similar study was done in Niger delta South-South Zone, Nigeria where the age highest prevalence of HIV was 20-29 years followed by 30-39years [15]. Another study in Nigeria showed highest prevalence of HIV among blood donors in age group 18-27 years [17]. Study in Mali showed that donors infected with $\mathrm{HIV}$ and $\mathrm{HBV}$ were younger than healthy donors, while those infected with HCV were older [22]. 
Nwokeukwu et al. Hematology and Leukemia 2014,

http://www.hoajonline.com/journals/pdf/2052-434X-2-4.pdf

\section{Conclusion/recommendations}

The sero-prevalence of HIV, HBV, HCV and Syphilis among prospective blood donors was low from our study. It could be that the people who know their status do not come for blood donation or probably as a result of challenges encountered in our regional blood banks. The major challenges confronting transfusion practice in sub-Saharan Africa include: the blood screening processes, mode of prospective donor selectivity and documentation. Any of these could account for the low seroprevalence of the above transfusion transmissible infections encountered in our study. There is need to scaleup the screening processes of blood in our regional blood banks to antigen-based method [27]. Similarly, the mode of selection of our prospective blood donors must be addressed as majority of them, if not all, are commercial (remunerated/ paid) donors. The benefits derived from this mode of donation have compromised the selectivity and safe blood practices criteria in our regional blood banks. This viscious cycle is also responsible for the improper documentation. The government and other donor agencies, as a matter of urgency, must come up with policies that will promote public awareness on safe blood practices through encouraging non-remunerated blood donation in our regional hospitals. These policies must address the above three aforementioned challenges in our regional blood banks at the three levels of health care deliveries if safe blood transfusion practices must work in sub-Saharan Africa.

\section{Limitations}

This study was constrained by small sample size. There is need to step-up the duration during subsequent retrospective studies to give room for larger population size. The documentation and screening processes, data analysis and demography of prospective blood donors must be improved in future similar studies.

\section{Competing interests}

The authors declare that they have no competing interests.

Authors' contributions

\begin{tabular}{|l|c|c|c|c|c|}
\hline Authors' contributions & HIN & CON & AC & EA & OAD \\
\hline Research concept and design & $\checkmark$ & $\checkmark$ & -- & -- & -- \\
\hline Collection and/or assembly of data & $\checkmark$ & $\checkmark$ & -- & $\checkmark$ & -- \\
\hline Data analysis and interpretation & $\checkmark$ & $\checkmark$ & -- & -- & -- \\
\hline Writing the article & $\checkmark$ & $\checkmark$ & -- & -- & -- \\
\hline Critical revision of the article & $\checkmark$ & $\checkmark$ & $\checkmark$ & $\checkmark$ & -- \\
\hline Final approval of article & $\checkmark$ & $\checkmark$ & -- & -- & -- \\
\hline
\end{tabular}

Acknowledgement

The authors wish to thank the Departments of Hematology and Community Medicine and the management of Federal Medical Centre, Umuahia for creating the enabling environment for this research study.

\section{Publication history}

EIC: Evangelos Terpos, University of Athens School of Medicine, Greece.
Received: 10-Oct-2013 Final Revised: 30-Jun-2014

Accepted: 01-Jul-2014 Published: 10-Jul-2014

\section{References}

1. Screening donated blood for transfusion transmissible infections: recommendations. WHO document 2010.

2. Tapko JB, Mainuka P and Diarra-Nama. Status of blood safety in the WHO African region: report of the 2006 survey. 2006.

3. Nagalo MB, Sanou M, Bisseye C, Kabore MI, Nebie YK, Kienou K, Kiba A, Dahourou H, Ouattara S, Zongo JD and Simpore J. Seroprevalence of human immunodeficiency virus, hepatitis $B$ and $C$ viruses and syphilis among blood donors in Koudougou (Burkina Faso) in 2009. Blood Transfus. 2011; 9:419-24. | Article | PubMed Abstract | PubMed Full Text

4. Allain JP, Stramer SL, Carneiro-Proietti AB, Martins ML, Lopes da Silva SN, Ribeiro M, Proietti FA and Reesink HW. Transfusion-transmitted infectious diseases. Biologicals. 2009; 37:71-7. | Article | PubMed

5. The national blood policy. National blood transfusion services. Federal ministry of health, Abuja, 2006.

6. Wallace/Maxcy-Rosenau-Last.Public Health and Preventive Medicine $15^{\text {th }}$ ed. United States of America McGraw-Hill. 2008; 191-221.

7. Baggaley RF, Boily MC, White RG and Alary M. Risk of HIV-1 transmission for parenteral exposure and blood transfusion: a systematic review and meta-analysis. AIDS. 2006; 20:805-12. | Article | PubMed

8. Lackritz EM. Prevention of HIV transmission by blood transfusion in the developing world: achievements and continuing challenges. AIDS. 1998; 12 Suppl A:S81-6. I PubMed

9. Christian ER. Hepatic tuberculosis in a patient with sickle-cell anemia who died of fatal post-transfusion hepatitis. Am Rev Tuberc. 1953; 67:247-57. | PubMed

10. Eldryd P, Richard G, David M and Geoffrey G. Principles of Medicine in Africa. $3^{\text {rd }}$ edition. Press syndicate, Cambridge, UK. 2004. 235-236.

11. Jayaraman S, Chalabi Z, Perel P, Guerriero C and Roberts I. The risk of transfusion-transmitted infections in sub-Saharan Africa. Transfusion. 2010; 50:433-42. I Article I PubMed

12. Traineau R, Elghouzzi MH and Bierling P. [Update on infectious risks associated with blood products]. Rev Prat. 2009; 59:86-9. | Article | PubMed

13. UNAIDS Document. 2013. I Pdf

14. Buseri FI, Muhibi MA and Jeremiah ZA. Sero-epidemiology of transfusiontransmissible infectious diseases among blood donors in Osogbo, southwest Nigeria. Blood Transfus. 2009; 7:293-9. | Article | PubMed Abstract I PubMed Full Text

15. Ejele OA, Nwauche CA and Erhabor O. Seroprevalence of HIV infection among blood donors in Port Harcourt, Nigeria. Niger J Med. 2005; 14:287-9. | PubMed

16. Olajubu FA, Osinupebi OA, Deji-Agboola M and Jagun EO. Seroprevalence of HIV among blood donors, antenatal women and other patients in a tertiary hospital in Nigeria. Braz J Infect Dis. 2009; 13:280-3. | Article | PubMed

17. Erhabor O, Ejele OA and Nwauche CA. The risk of transfusion-acquired hepatitis-C virus infection among blood donors in Port Harcourt: the question of blood safety in Nigeria. Niger J Clin Pract. 2006; 9:18-21. | Article | PubMed

18. Nwogoh B, Ikpomwen OD and Isoa EM. Donor blood procurement and the risk of transfusion transmissible viral infections in a tertiary health facility in South-South Nigeria. Niger Med J. 2011; 52:227-9. | Article | PubMed Abstract | PubMed Full Text

19. Salawu $L$ and Murainah HA. Pre-donation screening of intending blood donors for antibodies to infectious agents in a Nigerian tertiary health institution: a pilot study. Afr J Med Med Sci. 2006; 35:453-6. I Article | PubMed

20. Nagalo BM, Bisseye C, Sanou M, Kienou K, Nebie YK, Kiba A, Dahourou H, Ouattara S, Nikiema JB, Moret R, Zongo JD and Simpore J. Seroprevalence and incidence of transfusion-transmitted infectious diseases among 
Nwokeukwu et al. Hematology and Leukemia 2014,

http://www.hoajonline.com/journals/pdf/2052-434X-2-4.pdf

blood donors from regional blood transfusion centres in Burkina Faso, West Africa. Trop Med Int Health. 2012; 17:247-53. | Article | PubMed

21. Mbanya DN, Takam D and Ndumbe PM. Serological findings amongst first-time blood donors in Yaounde, Cameroon: is safe donation a reality or a myth? Transfus Med. 2003; 13:267-73. | Article | PubMed

22. Kone MC, Sidibe ET, Malle KK, Beye SA, Lurton G, Dao S and Diarra MT. [Seroprevalence of human immunodeficiency virus, hepatitis $B$ virus and hepatitis $\mathrm{C}$ virus among blood donors in Segou, Mali]. Med Sante Trop. 2012; 22:97-8. | PubMed

23. Stokx J, Gillet P, De Weggheleire A, Casas EC, Maendaenda R, Beulane AJ, Jani IV, Kidane S, Mosse CD, Jacobs J and Bottieau E. Seroprevalence of transfusion-transmissible infections and evaluation of the pre-donation screening performance at the Provincial Hospital of Tete, Mozambique. BMC Infect Dis. 2011; 11:141. | Article | PubMed Abstract | PubMed Full $\underline{\text { Text }}$

24. Lackritz EM. Prevention of HIV transmission by blood transfusion in the developing world: achievements and continuing challenges. AIDS. 1998; 12 Suppl A:S81-6. | PubMed

25. Namululi BA, Guerrieri $C$ and Dramaix MW. [Prevalence and incidence of HIV and hepatitis B among blood donors and estimated residual risk of transmission of HIV and HBV virus by blood transfusion. A study at the Provincial General Referee Hospital Bukavu, Democratic Republic of the Congo]. Rev Epidemiol Sante Publique. 2013; 61:139-44. | Article I PubMed

26. Matee MI, Magesa PM and Lyamuya EF. Seroprevalence of human immunodeficiency virus, hepatitis $B$ and $C$ viruses and syphilis infections among blood donors at the Muhimbili National Hospital in Dar es Salaam, Tanzania. BMC Public Health. 2006; 6:21. | Article | PubMed Abstract | PubMed Full Text

27. Nwabuko CO, Nnoli MA and Okoh AD et al. Taming the tide of HIV and TTI scourge in sub-Saharan Africa using autologous blood transfusion. Hematology and Leukemia. 2013; 1:5. I Article

\section{Citation:}

Ijeoma Nwokeukwu H, Ogbonna Nwabuko C, Chuku A, Ajuogu E and Adaunwa Dorathy O. Prevalence of human immunodeficiency virus, hepatitis $B$ virus, hepatitis $C$ virus, and syphilis in blood donors in a tertiary health facility in south eastern Nigeria. Hematol Leuk. 2014; 2:4.

http://dx.doi.org/10.7243/2052-434X-2-4 